\title{
ASSESSING THE OPINIONS OF PEDAGOGICAL SPECIALITIES STUDENTS ON THE USE OF DISTANCE LEARNING
}

\begin{abstract}
In recent years, distance learning has made considerable advances, with students working towards varied professions using this pedagogical method. The aim of this study was to assess the awareness and experiences of full-time and part-time pedagogical specialities students from the University of Latvia about distance learning. An electronic survey of these students, on their knowledge and opinions toward distance learning, was carried out. The results of the research show that pedagogical specialities students are poorly informed about possibilities of obtaining an education through distance learning. The majority of the surveyed students ( $78 \%$ of full-time students and $69 \%$ of part-time students) had no distance learning experience, with more part-time students having previous contact with distance learning methods than full-time students. Many surveyed students agree with the point of view that distance learning could be successfully used in secondary school and higher education level, with the majority of students believing that, in the future, distance learning will become a more dominant form of education. The majority of participants studying part-time (68\%) accept the use of distance learning in teacher training, but the majority of surveyed full-time students (56\%) do not accept the use of distance learning in teacher training.
\end{abstract}

Keywords: distance learning, pedagogical specialities, full-time students, part-time students, education levels, teacher training.

\section{Introduction}

In recent years, the use of information technologies, mobile devices, and social media in education has grown rapidly, meeting the evolving needs of students, professionals, and academics (Ordonez de Pablos, Tennyson, 2015). By using distance learning it is possible to link traditional lessons with new information and communication technologies in a flexible way. 
Distance learning is a form of education where students study and get an education at a distance from study site, if a computer with an internet connection is available. Distance learning is characterised by specially structured study materials and individual learning rates. A specifically organised assessment of educational achievements is used in it. Having a full-time job, accessibility and flexibility, individual responsibility, effective time management, physical distance, institutional prestige, and disability are the common factors influencing a preference amongst undergraduate and graduate learners for online learning (Hale, Yasemin, 2017). Distance learning systems, in the form of internet-supported platforms, offer numerous possibilities for creating different teaching and learning modes, based on the important pre-conditions of communication, interaction, and collaboration (Barjaktarović, Stanković, 2014).

Students generally hold a positive perception and attitude towards open and distance learning, compared to traditional forms of higher education (Ojo, Olakulehin, 2006). For example, findings have demonstrated that the reaction-based satisfaction level of Kuwait University students in online education is significantly high. About $95 \%$ of the participants, asserted that they are eager to take more training courses offered online (Safar, 2012). Research at Florida public university, which offers various degrees at undergraduate and graduate levels, suggests that those students who had never dropped an online course were influenced by instructional strategies and interaction and were satisfied with their online courses, thus remaining enrolled and engaged (Wise, 2012). The satisfaction level of students in Kocaeli University (Turkey) with regard to e-education courses is moderate; when the sub-dimensions were examined, satisfaction was high in terms of the instructor-student interaction and environment design sub-dimensions, while it was moderate in terms of the course content and teaching process, materials used, and communication tools. When interaction and communication tools, such as a virtual classroom, forum, chat, e-mail, web page, animation, video, graphics and images as content tools, and questionnaires as assessment tools, were used, satisfaction was higher in these courses (Topal, 2016). Analyses carried out indicate that the level of intrinsic motivation amongst open and distance education students is high in e-learning environments (Firat, Kilinc, 2018).

There are different advantages of distance learning in comparison with traditional study methods. Among them are the opportunity to create your own learning schedule, the ability to live and study away from an educator, and to combine studies with full-time work and other obligations. At the same time, the direct contact with educators is not so close, and it could lead to difficulties obtain complex professions. It is recommended that studies using distance learning involve additional learning time, 
instructional resources, and course elements that encourage interactions among learners (Means, Toyama, 2013).

The main risks of distance education are concentrated in two dimensions. The first is "basic or general" with high incidence of "fear of making mistakes" and "ignorance of the course content", while the second "own and beyond students' circumstances" where it is important to stand out the risks not directly controlled by the students: "warning from the authorities for not developing the program", "isolation from teachers" and "delegation of control" (Vazquez-Cano, Sevillano, 2015). The following elements are crucial in order for the distance learning environment to be effective: smooth communication between online students and the instructor, smooth communication between the online students and classroom students, the engagement of the online students and the redesign of certain instructional activities, balanced attention from the instructor to the students, and a high quality of audio (Wang, Huang, 2018).

In recent years, distance learning has advanced considerably. The expansion of distance learning and an understanding of its benefits has led to the growth of methodologies, pedagogies, and models aimed at diversifying and maximising the student experience and increasing student numbers (Gauld, Whatley, 2017).

The fields of distance and online education are experiencing continuing growth. Starting from simple forms of correspondence courses, this field has passed through various generations, employing various forms of simple and complex technology, like radios, televisions, computers, satellites, the internet, Wikis, and Web 2.0 applications (Demiray, Sever, 2009).

Massive Open Online Courses (MOOCs) are an innovative form of free distance learning which is represented by full-fledged interactive training courses, openly accessible on the internet for the simultaneous participation of a large number of people (Avshenyuk, 2016). MOOCs are serving non-consumers. Although they are limited in the services they provide compared with traditional colleges, they offer free and accessible education to a broader audience who cannot afford the traditional provision. However, this is a characteristic of online distance learning in its broadest sense. For MOOCs to be disruptive, they have to open up markets by competing with existing firms, using low-cost business models, improvements beyond the level of the original competitors, taking price differences into account, and replacing the established firms (Langen, van den Bosch, 2013). In 2012, DOCCs (Distributed Open Collaborative Courses) were developed, which allow the theme and course organisation to change based on the students' intervention. Similarly, SPOCs (Self-Paced Online Courses), enhance student flexibility in terms of the learning start and the rhythmicity of the study (Nuta, Pusca, 2017). There are different innovations in 
distance education, such as software applications, open source courseware, online learning platforms, and web 2.0 technologies. Coupled with this, there is increasing interest and debate around the possibilities that novel innovations can have on changing education practices and providing more effective learning solutions (Carrier, 2017).

Teacher education and open and distance learning are complex and critically important fields of endeavour. Used together, they have the potential to enhance the effective, efficient, and equitable provision of education, and to maximise access to such provision to various categories of disadvantaged learners (Umar, Danaher, 2010). Teacher training is increasingly emphasising social competencies and intercultural awareness. Online pedagogies based on sociocultural methods can support productive learning communities that span diverse cultural backgrounds. The cultural dimensions of learning frameworks could provide a useful stimulus to promote discussion amongst learners and teachers that could raise awareness of the cultural basis of a diversity of approaches to learning (Hunt, Tickner, 2015). With the rise of distance education, progressive research on the best methods, tools, and technologies in the field is necessary to continue to take advantage of the pedagogical opportunities and improvements offered through remote learning platforms (Yuzer, Gulsun, 2014).

Throughout the world, open and distance learning has been used for inservice teacher education over many years, in different education systems and in diverse social and cultural contexts (Harreveld, 2010). However, teacher training always sits within national and international policy frameworks and is subject to the vagaries often associated with the policy (Simpson, Kehrwald, 2010). Networked computing and communications technologies open up new delivery possibilities for both the distance and face-to-face delivery of teacher education. Blended (or hybrid) learning which combines not only modes of delivery but also approaches to teaching and learning has emerged as a powerful option for teacher education providers wishing to tailor their programmes to suit increasingly diverse and dispersed cohorts of learners (Simpson, Kehrwald, 2010).

The aim of this study was to assess the awareness and experiences of full-time and part-time pedagogical specialities students from the University of Latvia in distance learning and gauge their opinion about the use of distance learning in different levels of education.

\section{Methods and Materials}

An electronic survey of pedagogical specialities students from the University of Latvia was carried out, regarding their knowledge and opinions towards distance learning. The questionnaire consisted of eight 
questions. Four of these were connected with students' awareness and experiences in distance learning, one question was about students' opinions of the use of distance learning in different educational levels, two questions were connected with students' opinions of the necessity for more detailed information about distance learning for students and perspectives of distance learning in future, and one question dealt with students' opinions regarding the use of distance learning in teacher training. The answers of full-time students and part-time students were compared. The questionnaire gave an understanding of the awareness and experiences of students with regard to distance learning, their point of view about the use of distance learning in different levels of education and the use of distance learning in future, and students' opinions about the use of distance learning in teacher training. The link to the questionnaire was sent to different full-time and part-time student groups. 46 full-time students and 62 part-time students from the University of Latvia were surveyed. SPSS statistical data processing software was used for statistical analysis, with the Mann-Whitney U test used for data analysis.

\section{Results and Discussions}

The results of the research show that the majority of full-time pedagogical specialities students are informed (46\%) or partly informed (31\%) about the possibilities of obtaining an education by using distance learning, with the majority of part-time students being partly informed (67\%) about possibilities to get an education by using distance learning (see Figure 1). Only $23 \%$ of full-time students and $11 \%$ of part-time students answered that they were not informed regarding the possibilities of obtaining an education by using distance learning.

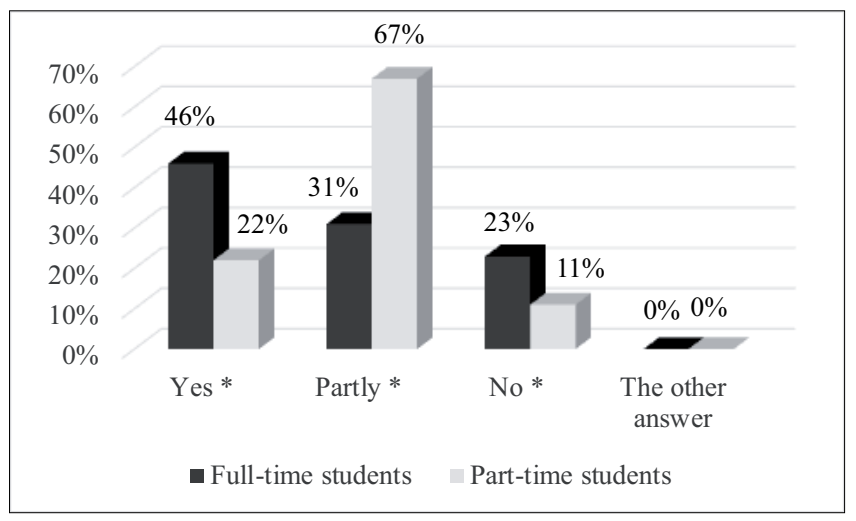

Figure 1. The opinions of students regarding their awareness about possibilities to obtain an education by using distance learning (in $\%$ of respondents in groups) ( $* p<0.05)$ 
The majority of students have no experience in the using of distance learning (see Figure 2).

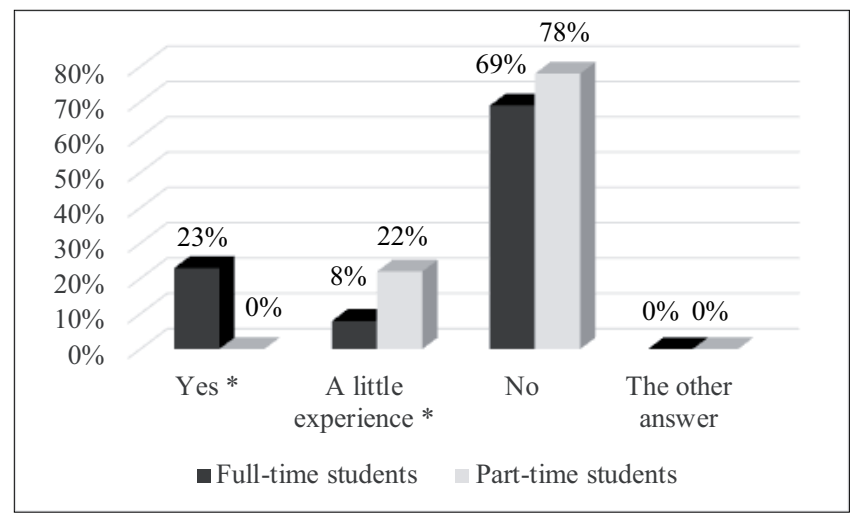

Figure 2. Students' experience of the use of distance learning (in $\%$ of respondents in groups) $(* p<0.05)$

$69 \%$ of full-time students and $78 \%$ of part-time students admit that they have not had such experience. Only $23 \%$ of full-time students have experience in distance learning. $22 \%$ of part-time students and $8 \%$ of fulltime students have a little experience in distance learning.

The majority of surveyed students had not used distance learning at school (see Figure 3). 78\% of full-time students and $61 \%$ of part-time students had not used distance learning at school, with $31 \%$ of surveyed part-time students and $22 \%$ of full-time students having had partly experiences with distance learning at school. Only $8 \%$ of part-time students had used distance learning at school.

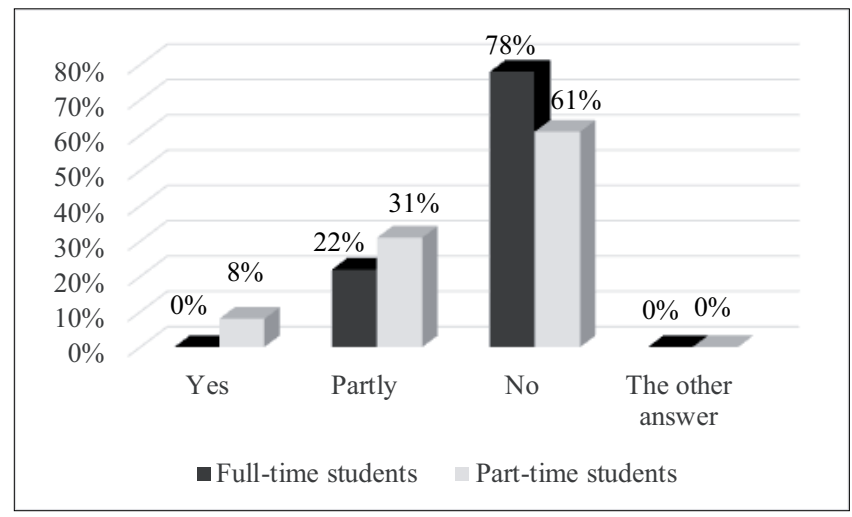

Figure 3. Students' views on their using of distance learning at school (in $\%$ of respondents in groups) 
The majority of surveyed students had not used distance learning at the university either (see Figure 4). $78 \%$ of full-time students and $46 \%$ of part-time students had not used distance learning at university. At the same time, $46 \%$ of part-time students had partly used, and $8 \%$ of parttime students had used, distance learning at university. Therefore, parttime students have more experience of distance learning at university in comparison with full-time students.

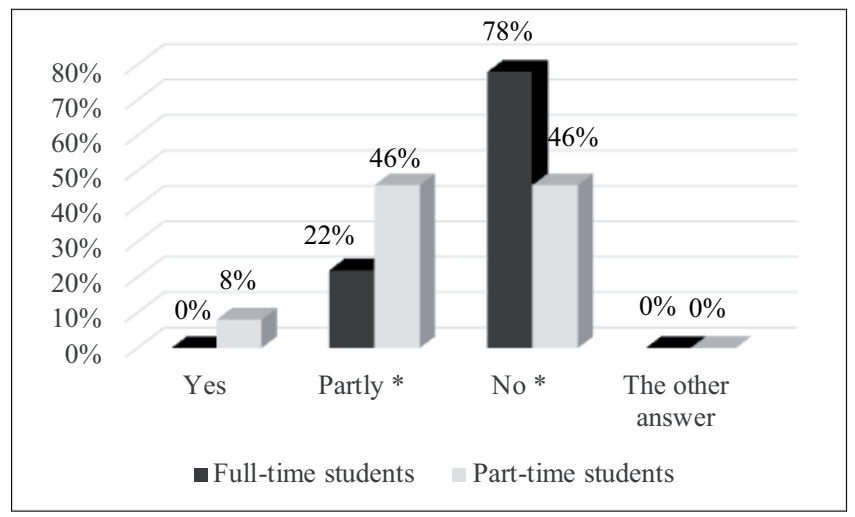

Figure 4. Students' views on their using of distance learning at university (in $\%$ of respondents in groups) ( $* p<0.05$ )

The majority of students agree with the opinion that distance learning could be used in higher education levels (see Table 1). $78 \%$ of surveyed full-time students do not support distance learning at the primary school level, and $67 \%$ of them do not support distance learning at the basic school level. Part-time students are less categorical, but the majority do not accept distance learning in primary (62\%) and basic school level (46\%) either. At the same time, $44 \%$ of full-time students accept, and $56 \%$ of them accept in some cases, distance learning at the secondary school level, with 78\% of full-time students accepting, and $22 \%$ of them accepting in some cases, distance learning in higher education level. 53\% of part-time students accept distance learning at the secondary school level and $77 \%$ of part-time students accept distance learning at the level of higher education.

The majority of part-time students (54\%) agree with the opinion that it is necessary to give students more detailed information about distance learning and its advantages (see Figure 5). It appears that full-time students are less interested in distance learning. 45\% of full-time students do not agree with the statement that it is necessary to give students more detailed information about distance learning and its advantages but 33\% of them rather agree to this statement. There are no students who strongly disagree with this statement. 
Table 1. The opinion of students regarding the use of distance learning at different education levels (in \% of respondents in groups)

\begin{tabular}{|c|c|c|c|c|c|c|c|c|}
\hline \multirow{2}{*}{$\begin{array}{c}\text { Levels of } \\
\text { education }\end{array}$} & \multicolumn{7}{|c|}{ The opinion of students } \\
\cline { 2 - 9 } & Accept & $\begin{array}{c}\text { Accept } \\
\text { in some } \\
\text { cases }\end{array}$ & $\begin{array}{c}\text { Do not } \\
\text { accept }\end{array}$ & $\begin{array}{c}\text { I have } \\
\text { no } \\
\text { opinion }\end{array}$ & Accept & $\begin{array}{c}\text { Accept } \\
\text { in some } \\
\text { cases }\end{array}$ & $\begin{array}{c}\text { Do not } \\
\text { accept }\end{array}$ & $\begin{array}{c}\text { I have } \\
\text { no } \\
\text { opinion }\end{array}$ \\
\hline $\begin{array}{c}\text { Primary } \\
\text { school level }\end{array}$ & 11 & 11 & 78 & 0 & 15 & 23 & 62 & 0 \\
\hline $\begin{array}{c}\text { Basic school } \\
\text { level }\end{array}$ & 11 & 22 & 67 & 0 & 23 & 31 & 46 & 0 \\
\hline $\begin{array}{c}\text { Secondary } \\
\text { school level }\end{array}$ & 44 & 56 & 0 & 0 & 53 & 47 & 0 & 0 \\
\hline $\begin{array}{c}\text { Higher edu- } \\
\text { cation level }\end{array}$ & 78 & 22 & 0 & 0 & 77 & 23 & 0 & 0 \\
\hline
\end{tabular}

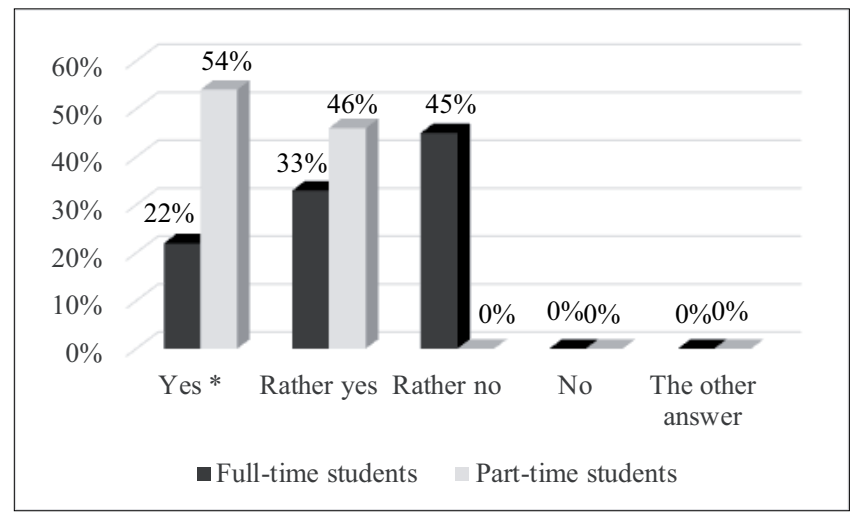

Figure 5. Students' opinions about whether it is necessary to give students more detailed information about distance learning and its advantages (in $\%$ of respondents in groups) ( $\left.{ }^{*} p<0.05\right)$

The majority of full-time (84\%), as well as part-time students 67\%), partly agree to the statement that distance learning will become the dominant form of education in the future (see Figure 6). More part-time students $(22 \%)$ in comparison with full-time students (8\%) strongly agree with this statement. 


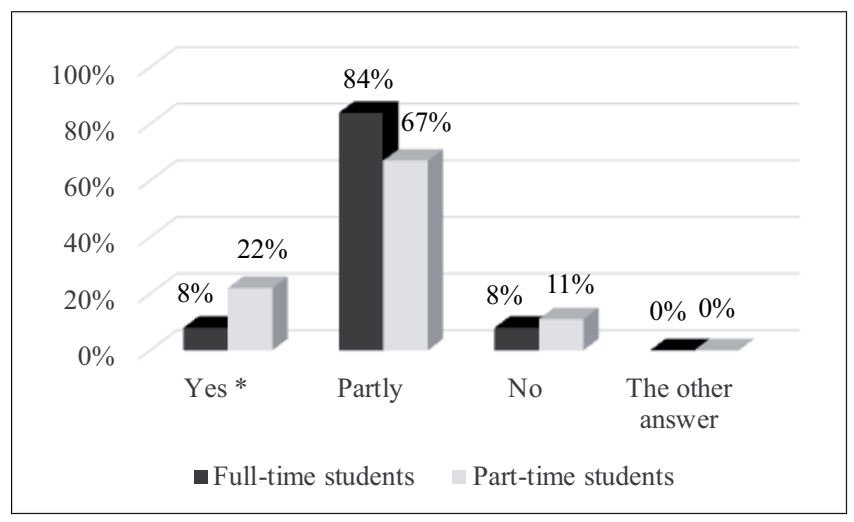

Figure 6. Students' opinions regarding distance learning becoming the dominant form of education in the future (in $\%$ of respondents in groups) (* $p<0.05$ )

Students have different opinions about the use of distance learning in teacher training (see Figure 7). 33\% of surveyed full-time students accept, and $11 \%$ of them rather accept, the use of distance learning in the teacher training. $33 \%$ of full-time students rather not accept the use of distance learning in teacher training, with $23 \%$ not accepting it. $22 \%$ of parttime students accept, and $46 \%$ of them rather accept, the use of distance learning in teacher training. However, $23 \%$ of part-time students rather not accept, and $8 \%$ of them do not accept, such use. The majority of surveyed pedagogical specialities students see the advantages of distance learning, but they suggest that it is necessary to have close contact with lecturers and teachers to take their experience and become a good teacher.

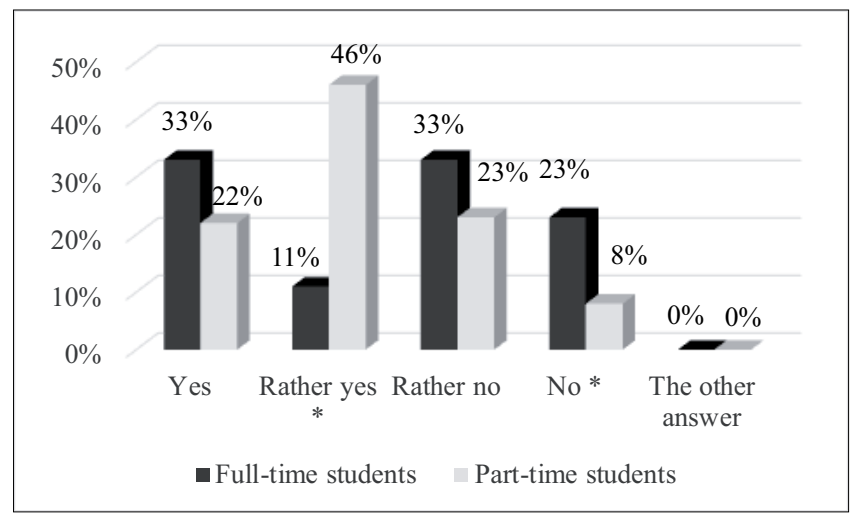

Figure 7. Students' opinions about the use of distance learning in teacher training (in $\%$ of respondents in groups) $(* p<0.05)$ 


\section{Conclusions}

1. Pedagogical specialities students from the University of Latvia are rather poorly informed about possibilities of obtaining an education using distance learning. The majority of surveyed students ( $78 \%$ of parttime students and $69 \%$ of full-time students) have no distance learning experience. Only $23 \%$ of full-time students have experience in distance learning.

2. More part-time students previously had contact with distance learning methods, when compared with full-time students in school and university. $31 \%$ of surveyed part-time students and $22 \%$ of full-time students having had partly experience with distance learning at school but $46 \%$ part-time students and $22 \%$ of full-time students having had partly experiences with distance learning at university.

3. The majority of pedagogical specialities students from the University of Latvia do not agree with the use of distance learning in primary school and basic school but agree or partly agree with the use of distance learning at the level of secondary school education or higher education. In comparison with full-time students, more part-time students admitted to the use of distance learning at the primary or basic school level. $23 \%$ of part-time students accept using of distance learning at the basic school level but only $11 \%$ of full-time students accept using of distance learning at this level.

4. All the surveyed pedagogical specialities part-time students, and $55 \%$ of the surveyed full-time students, consider that it is necessary to give students more detailed information about distance learning and its advantages. Part-time students are more interested in the distribution of information about distance learning in comparison with full-time students.

5. The majority of surveyed pedagogical specialities students ( $92 \%$ of fulltime students and $89 \%$ of part-time students) consider that distance learning will become, or partly become, the dominant form of education in future.

6. Students have different opinions about the use of distance learning in teacher training. The majority of surveyed part-time students (68\%) accept or rather accept the use of distance learning in teacher training. However, the majority of surveyed full-time students (56\%) do not accept, or rather do not accept, the use of distance learning in the teacher training. Only $22 \%$ of full-time students fully accept distance learning in the teacher training. At the same time $33 \%$ of part-time students fully accept distance learning in the teacher training. 


\section{References}

Avshenyuk, N. (2016). Priority Fields of Teachers' Professional Development in Terms of Open Education Worldwide. Comparative Professional Pedagogy, 6(4), 15-19.

Barjaktarović, L., Stanković, J., \& Gavrilović, J. (2014). The Role of Internet Technologies in Lecturing and Learning. Singidunum Journal of Applied Sciences. Supplement, 397-401.

Carrier, N. (2017). How educational ideas catch on: the promotion of popular education innovations and the role of evidence. Educational Research, 59(2), 228-240.

Demiray, U., \& Sever, N. S. (2009). Marketing Strategies in Open Distance Learning and Online Education. In: Demiray, U., Sever, N. S. (Eds.) The Challenges for Marketing Distance Education in Online Environment: An Intergrated Approach (pp. 3-68). Anadolu University: Eskisehir-Turkey.

Firat, M., Kilinc, H., \& Yuzer, T. V. (2018). Level of Intrinsic Motivation of Distance Education Students in e-learning Environments. Journal of Computer Assisted Learning, 34(1), 63-70.

Gauld, C., \& Whatley, P. (2017). Distance Learning for Information Professionals: A Practical, Reality-driven Model for Postgraduate Education. Education for Information, 33, 121-133.

Hale, I., \& Yasemin, G. (2017). Why Do Learners Choose Online Learning: The Learners' Voices. International Conference on E-Learning. Lisbon, Portugal, Jul 20-22, 2017. ISBN: 978-989-8533-63-0. Retrieved from: https://eric.ed.gov/contentdelivery/servlet/ ERICServlet $?$ accno $=$ ED579379.

Harreveld, R. E. (2010). A Capability Approach to Open and Distance Learning for In-Service Teacher Education. In: Danaher, P. A. \& Umar, A. (Eds.) Teacher Education through Open and Distance Learning (pp. 47-60). Vancouver: Commonwealth of Learning.

Hunt, A., \& Tickner, S. (2015). Cultural Dimensions of Learning in Online Teacher Education Courses. Journal of Open, Flexible and Distance Learning, 19(2), 25-47.

Langen, H. \& van den Bosch, H. (2013). Massive Open Online Courses: disruptive innovations or disturbing inventions? Open Learning, 28(3), 216-226.

Means, B., Toyama, Y., Murphy, R. F., \& Baki, M. (2013). The Effectiveness of Online and Blended Learning: A Meta-Analysis of the Empirical Literature. Teachers College Record, 115(3), 1-47.

Nuta, A. C., \& Pusca, A. C. (2017). An Assessment of Distance Learning Education Platform Options and Opportunity. Journal of Public Administration, Finance \& Law, 11, 113-120.

Ojo, D. O., \& Olakulehin, F. K. (2006). Attitudes and Perceptions of Students to Open and Distance Learning in Nigeria. International Review of Research in Open and Distance Learning, 7(1), 1-10.

Ordonez de Pablos, P., Tennyson, R. D., \& Lytras, M. D. (2015). Assessing the Role of Mobile Technologies and Distance Learning in Higher Education. Hershey, PA: IGI Global.

Safar, A. H. (2012). The Students' Perspectives of Online Training at Kuwait University. College Student Journal, 46(2), 436-458.

Simpson, M., \& Kehrwald, B. (2010). Educational Principles and Policies Framing Teacher Education through Open and Distance Learning. In: Danaher, P. A. \& Umar, A. (Eds.) Teacher Education through Open and Distance Learning (pp. 23-34). Vancouver: Commonwealth of Learning. 
Topal, A. D. (2016). Examination of University Students' Level of Satisfaction and Readiness for E-Courses and the Relationship between Them. European Journal of Contemporary Education, 15(1), 7-23.

Umar, A., \& Danaher, P. A. (2010). Setting the Scene for Interrogating Teacher Education through Open and Distance Learning. In: Danaher, P. A. \& Umar, A. (Eds.) Teacher Education through Open and Distance Learning (pp. 1-6). Vancouver: Commonwealth of Learning.

Vazquez-Cano, E., Sevillano, G., \& Ma, L. (2015). Analysis of Risks in a Learning Management System: A Case Study in the Spanish National University of Distance Education (UNED). Journal of New Approaches in Educational Research, 4(1), 62-68.

Wang, Q. Y., Huang, C. Q., \& Quek, C. L. (2018). Students' Perspectives on the Design and Implementation of a Blended Synchronous Learning Environment. Australasian Journal of Educational Technology, 34(1), 1-13.

Wise, T. L. (2012). The Influence of Interactivity and Instructional Strategies on Retention and Satisfaction in Distance Learning Environments. (Doctoral dissertation). The University of West Florida, 85 pp. Available: ProQuest LLC. 789 East Eisenhower Parkway, P. O. Box 1346, Ann Arbor, MI 48106. Tel: 800-521-0600. Retrieved from http://datubazes. lanet.lv:2236/en-US/products/dissertations/individuals.shtml.

Yuzer, V. T., \& Gulsun, E. (2014). Handbook of Research on Emerging Priorities and Trends in Distance Education: Communication, Pedagogy, and Technology. Hershey, PA: IGI Global. 